Dakhli, Z., Lagier, S., Ducoulombier, L., and Lafhaj, Z. (2017). "Economics of Using a Distribution Centre for a Renovation Housing Project." In: Proc. $27^{\text {th }}$ Annual Conference of the International. Group for Lean Construction (IGLC), Pasquire C. and Hamzeh F.R. (ed.), Dublin, Ireland, pp. 641-652. DOI: https://doi.org/10.24928/2019//0212 . Available at: <www.iglc.net>.

\title{
ECONOMICS OF USING A DISTRIBUTION CENTER FOR A RENOVATION HOUSING PROJECT
}

\author{
Zakaria Dakhli ${ }^{1}$, Steven Lagier ${ }^{2}$, Laure Ducoulombier ${ }^{3}$ and Zoubeir Lafhaj ${ }^{4}$
}

\begin{abstract}
The use of a distribution center is a common practice in industry and an emerging practice in construction. The main reason is that logistics is not considered to be the primary concern and interest of construction. On the other hand, current research shows that construction can be considered as a kind of production. The logistics side in construction is underrrated, especially since the cost of materials constitutes a large proportion of the cost of construction. While the research conducted on the use of distribution centers shows some benefits, a comparative cost between this type of logistics and the traditional method of supply has not yet been carried out in detail. The lack of figures and extensive studies makes it difficult for professionals to adopt it. The case study in this paper highlights the economics of using a distribution center for a housing renovation project. the paper also suggests a practical framework that assess the economics of using a distribution center in for housing.
\end{abstract}

\section{KEYWORDS}

Construction site, supply chain, distribution center, third party logistics, logistics, cost, benefits, lean construction

\section{INTRODUCTION}

Increasing the margin for construction companies goes hand in hand with the exploration of continuous improvement techniques such as those provided by Lean Construction (Howell and Ballard 1998; Arbulu and Ballard 2004). Another type of change concern the application of industrialized building systems (Warszawski 2003). Gains are also reported thanks to the use of BIM and technology enabled improvements and robotics as well (Eadie et al. 2013; Lin et al. 2014; Bock 2015).

Construction logistics are, on the other hand, an inherent component of the construction practice (Jasti and Kodali 2014; Dotoli et al. 2015). Moving in and out materials is the obvious form of construction logistics. There are also financial and information flows

\footnotetext{
1 Professor, Civil and Envir. Engrg. Dept., Director of the Project Production Systems Lab., Univ. of California, Berkeley, CA 94720-1712, USA, +1 510 643-8678, tommelein@ berkeley.edu

2 Managing Director, The Change Business Ltd., Stroud, United Kingdom, +44 7968485627 , alanmossman@mac.com
} 
which are more difficult to assess and to track meticulously in a construction project because of the large number of transactions in a project lifetime (sometimes even in a single day).

In this context, logistics could be a performance leverage for the construction industry (Ghanem et al. 2018). A great number of construction managers doesn't see logistics as a critical point in construction (Caldas et al. 2014) but thinks of it as a by-product when managing construction projects. (Vidalakis et al. 2011) agree on the importance of intermediary organizations in best managing construction logistics. An array of research presents case studies on the use of third party logistics in construction (Ekeskär 2016; Sundquist et al. 2017), network design models for construction logistics (MotaghediLarijani et al. 2012), and models / simulations ( $\mathrm{Ng}$ et al. 2008; Vidalakis et al. 2011). However, few research focus on the economics underlying such logistics systems in construction.

Distribution centers in construction are mainly used to rationalize the distrubiton by packaging the components and delivering them together to site. In other words, distribution centers are used as a buffer and a method of supply for clustering elements intended to be assembled together. For construction, it means delivering a package composed of construction products intended to be utilized on the site. A consequent number of research is conducted to explore this practice in construction. (Court et al. 2006) implemented this for a large mechanical and electrical project. They divided the components into 3 categories: $\mathrm{A}, \mathrm{B}, \mathrm{C}$. «A $\mathrm{A}$ " category comprises modular product and they are shipped directly onsite. Category " $\mathrm{B}$ " is for "components from suppliers" and "C" "Consumables from suppliers". Those two categories are subjected to Kitting via a fast Kitting supply channel to the site. In a variety of case studies, distribution center logistics are outsourced to a third party logistics (Vaha et al. 2004). Distribution centers are well adopted in the UK where the Kitting practice is supported by the government (EC Harris 2013). This is due to a difficult access to cities, the aim being to reduce transportation flows (in \& out).

This research article is an attempt to measure the economics of using a distribution center to manage construction logistics. For that, we formulated indicators to assess the impact of the logistics approach and analyse them to help the scientific community derive general.

\section{CASE STUDY}

The case study is a rehabilitation operation in an occupied environment of a former mining city with 184 housing units located in the city of Lens. This operation is a follow up of a previous similar operation (similar types of housing) in Lens (the same district) that rehabilitated 95 houses, and was carried out few years ago by the same general contractor. Both operations are carried out by the same general contractor. The Lens 95 project was carried out following a "classic logistics" approach, which means without the use of a consolidation center, while the Lens 184 operation used a third party logistics provider, combined with some lean tools for project management (details in the following section). 


\section{WORK REPARTITION}

Part of the work was realized by the general contractor and the rest was subcontracted as described in Table 1. For the plastering work, half of the housing units are realized by the general contractor and the rest by the subcontractor.

Table 1: Work repartition

\begin{tabular}{cc}
\hline Contracted work & Sub-contracted work \\
\hline Border tiles. electric & building curage (structural cleaning) \\
switchboards. & Roofing and house covering \\
Floors & Asbestos disposal \\
Sanitation & Coatings, painting \\
External woodworks, windows & Plastering work (50\%) \\
Plastering work (50\%) & Floor coverings \\
Plumbing & Electricity, gas \\
\hline
\end{tabular}

\section{PlanNing AND Labour MaNAGement}

Average number of employees: 22 workers for the general contractor and 80 in total. Typical work cycle:

- 20 simultaneous houses.

- Delivery of 3 units (houses) per week.

Example of the planning for one house:

- The tenant moves on Monday.

- The work is realized in a 8 to 10 weeks timeframe.

- During the last week:

Wednesday: Pre-reception meeting with the tenant.

Thursday: final quality checks with tenant.

Friday: tenant moves to his renovated house.

\section{THE LOGISTICS APPROACH}

The operation's site has a limited space available for the storage purposes, which in fact implies more frequent deliveries from suppliers. Therefore, It appears that the use of a buffer stock outside the renovation site is more advantageous in terms of delivery and order management. It should be noted, however, that all subcontractors have maintained a traditional procurement approach. Only the general contractor was involved in the logistics 
developed with the distribution center. The characteristics of the distribution center's supply chain are as follow:

- Buffer stock (consolidation centre) 10 minutes from the site.

- Delivery frequency : Monday-Wednesday-Thursday.

- Delivery on D-1 on site (just-in-time).

- Order preparation time: 3 hours.
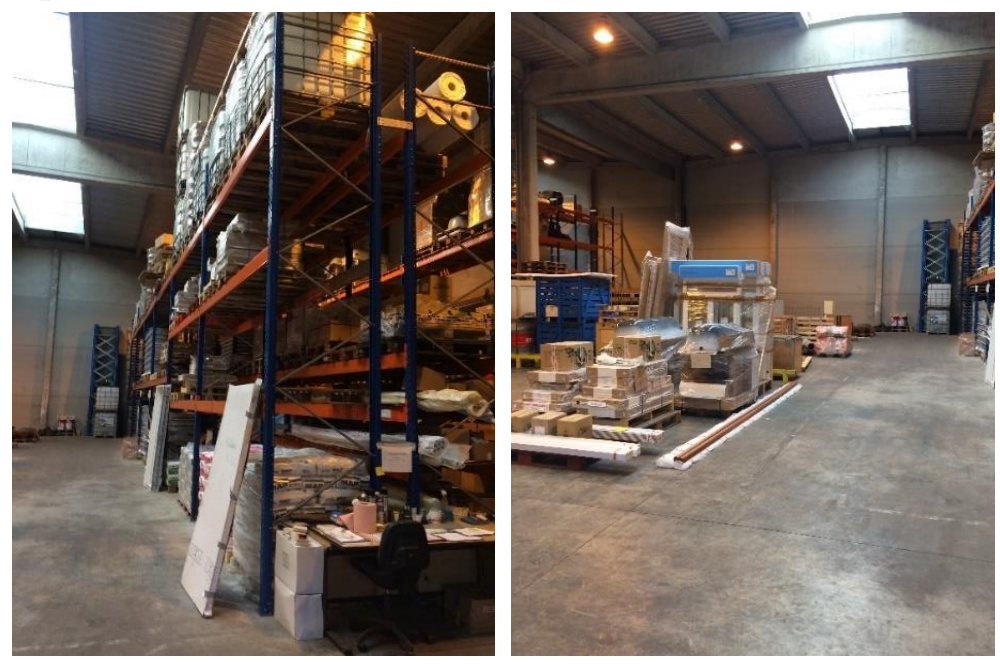

Figure 1: Storage at the distribution center

Lean Construction elements were used to support the logistics approach. More specifically, the following:

- Adaptation of the LPS (Last Planner System): planning, work preparation, and first run studies.

- Visual management (tables and screens to visual data site).

- Follow-up of the work for each house with coloured tablets.

- Organisation of teams to standardise the work (rail teams, dubbing and placo...).

- Creation of tools to promote productivity and ergonomics (tool trailers).

- The use of the digital model and a tablet interface for the various housing information.

- Autonomous teams: those teams are onsite, multidisciplinary, and follow the work sequence thanks to LPS.

Figure 2: Lean Construction elements used to support the logistics approach 

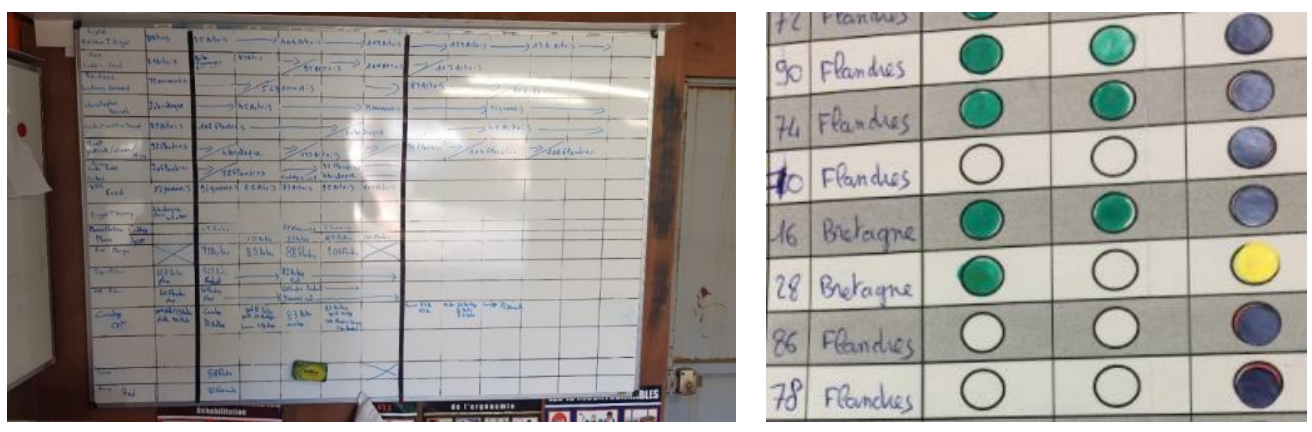

\section{SCOPE OF THE STUDY}

Every month, the construction manager analyses the site budget. The figures make it possible to compare the estimated budget of the operation and the progress made as a function of the actual expenditure, mainly in terms of materials purchased and man-hours consumed. These different expenses are subdivided into tasks and work trades.

Since the logistics approach implemented is only deployed for the general contractor, this research study do not investigate the use of the distribution center by subcontractors.

\section{BUDGET FORMULATION}

An important aspect of the budget management and monitoring is the concept of budget and expenditure converted in man-hours. The method used is similar to the Earned Value Methode (EVM). Since the main resource is the "time" of work, it is often more relevant to quantify expenses at first glance in terms of hours rather than in euros. This approach is also found within the engineering offices that prepare before the actual excuction of work. Indeed, this department is required to carry out an objective planning of the operation with a manpower curve and a budget in man.hours. This document serves as a guide for the construction manager.

Every month, the construction manager provides information on the actual progress in terms of the number of houses renovated. For this case study, this is the most telling progress indicator. In fact, we have a clearer idea of the progress of the project with a measure such as: "90 houses completed out of 184" rather than the measure "1100 plates of plasterboard installed out of 2000".

As explained above, project expenses are analysed in terms of man.hours and therefore can easily be converted into euros if necessary using an average hourly rate.

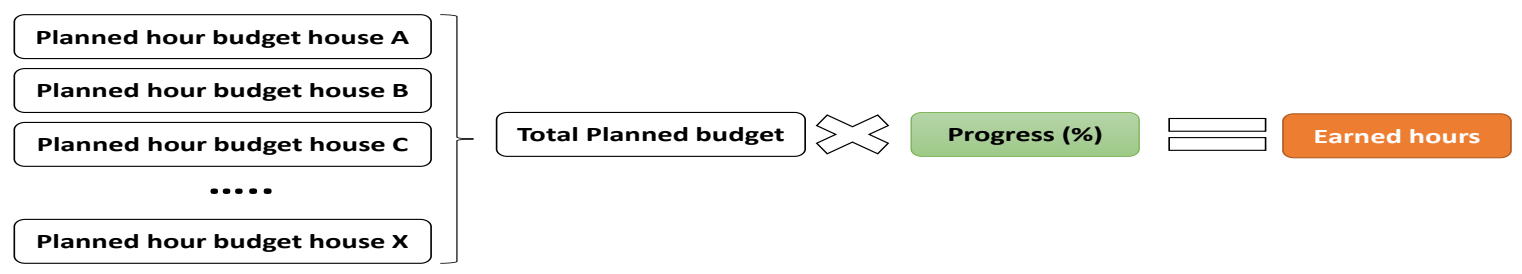

Figure 3: How the budget is controled 
Figure 3 shows the indicator used by the construction manager to analyse the labour expenditure of the operation. A planned budget per house was previously established during the design phase, which corresponds to the estimated number of man.hours. This gives a total estimated budget of man.hours for all 184 units. From there, the construction manager informs the number of housing units built for each trade, resulting in a percentage of progress as a function of the total number of houses. Therefore, for each trade, we can know the number of estimated hours allocated as a function of the actual progress. This indicator is called: the number of "earned" hours. In other words, it is the budget expressed as the estimated hours in view of the actual progress of the project ("to achieve what has been done so far, so many hours had been planned").

This indicator is directly compared with the actual number of hours spent, which corresponds for each task and trade to the sum of the companions' daily scores. This is therefore the real expenditure of man.hours. We therefore obtain a difference in expenditure (in hours) between the forecast and the actual as shown in Figure 4.

\section{Actual hours}

\section{Earned hours}

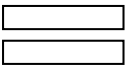

expenditure gap

Figure 4: Calculation of the expenditure gap

The budget is also composed of materials and various ancillary costs. However, we will not study these cases because they are not affected by the lean and/or logistics approach. As an example, if we take the example of a plasterboard partition, the quantities of materials to be used to make it are independent of the organization of the renovation site.

\section{THE PLANNED BUDGET}

Thanks to the experience gained on the previous similar renovation project on Lens 95, the general contractor established the estimated hour budget of Lens 184 project based on the actual hour budget of Lens 95. Nevertheless, it was necessary to take into account the supposed gains of the logistics service implemented on Lens 184, which directly translates into a time saving in terms of handling the various elements. Handling times were therefore estimated for each concerned task and trade. This amount of hours was therefore deducted from the actual budget of Lens 95 based on the allocation of materials for each trade. As a consequence, it is possible to establish a budget in hours (subsequently converted into euros) to be allocated to the logistics service as shown in Figure 5.

\section{Budget hours Lens 184}

Budget allocated for logistics
Budget hours Lens 95

Estimated hours for handling
Budget hours for handling

Hourly rate

Figure 5: Forumulation of the provisional budget 


\section{FORMULATION OF THE COST INDICATOR}

For this type of operation, the cost indicator "number of hours per house" is representative of the yield and makes it possible to correlate the quantity of resources (hours) with the planning and deadlines, as shown in Figure 6. Indeed, the duration of the operation, through the planning, is a commitment of the general contractor towards the owner. So we can consider that the excecution time for a typical house fixed. However, this is rarely the case with regard to the quantity of resources (mainly labor) to be implemented. As a result, the general contractor adjusts many variables orders to meet the deadlines. Thus, for a given implementation period, the least resources (hours) are consumed, the smallest the ratio "number of hours per house" is. Moreover, if the general contractor wishes to allocate more resources to make up for a delay, the ratio of "number of hours per house" will deteriorate. We therefore have an indicator that reflects economic profitability by directly integrating completion times.

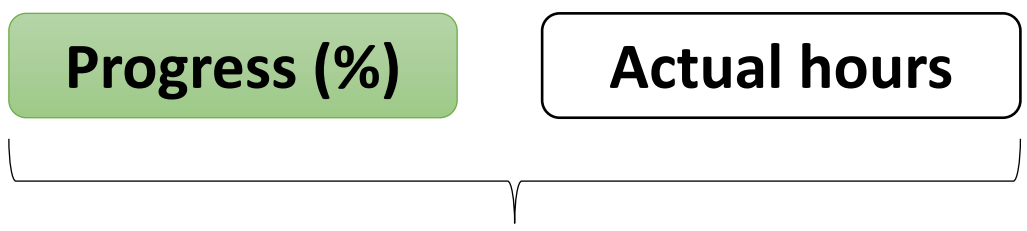

\section{Ratio: number of hours per house}

Figure 6: Formulation of the indicator "number of hours per house"

\section{HOW THE INDICATOR WAS USED?}

The allocated budget for Lens 95 and the planned budget of Lens 184, built on the basis of that of Lens 95 by means of the logistics budget (estimated handling hours), will serve as a basis for comparisons as shown in Figure 7. The same reasoning as for the actual ratio can be applied.

Nbr hours/ house - Lens 95

Nbr hours/ house -

Planned for Lens 184
Progress (\%)

Progress (\%)
Budget hours baseline Lens 95

Budget hours lens 184

Figure 7: Forumulation of ratios "number of hours per house"

\section{RESULTS AND DISUCSSION}

A first analysis consists in taking into account all the trades realized by the general contractor and determining the "number of hours per house" ratio as presented in Figure 8. 


\section{Nbr hours/ house - Lens 95}

\section{Nbr hours/ house - \\ Planned for Lens 184}

\section{Nbr hours/ house -} Actual for Lens 184

\section{9 hrs / house}

\section{9 hrs / house}

\section{8 hrs / house}

Figure 8: Results of the different ratios number of hours per dwelling

We observe a real gain compared to what was achieved on the previous operation Lens 95 and even compared to what was estimated for the Lens 184 site including the logistician service. However, this overall ratio hides the potential disparities between the different trades. In other words, the ratio does not provide information on what trade is actually impacted by the distribution center service and where lies the cost benefits for each trade.

Table 2 presents the breakdown of the various "number of hours per dwelling" ratios according to the tasks and batches of the operation. There is therefore a disparity of gains between the different batches, so it is natural to ask the question of which batches allow an overall gain and what are their weights compared to the other batches. Indeed, the more hours allocated to a lot is important in relation to the total, the more this lot will influence the number of hours per dwelling. The supervision task in question comes from the budget in hours allocated to the assistant site manager. Even if this was used to constitute the logistics budget, this data corresponds more to a financial charge due to the change in status of the assistant site manager than to a physical reality. This will therefore not be analysed in detail later on.

Table 2: Breakdown of the different ratios number of hours per house

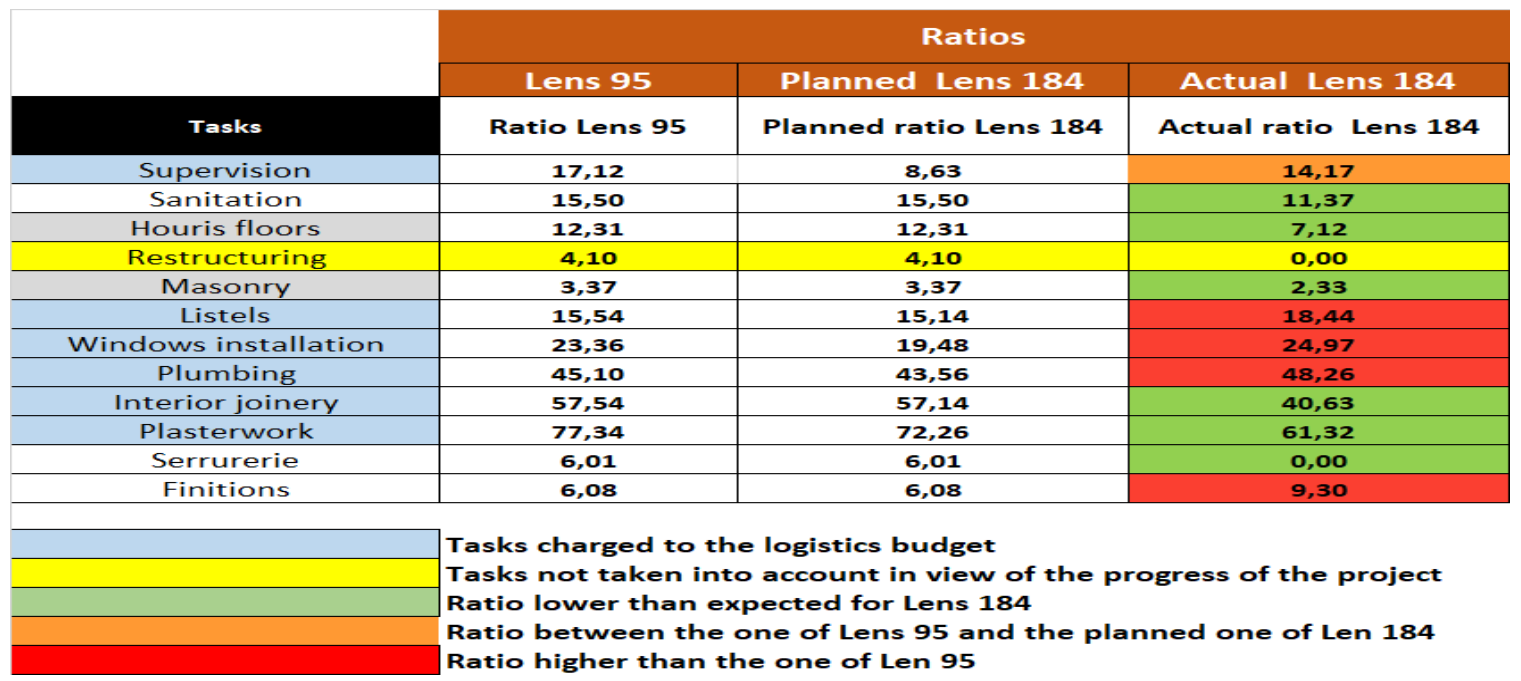


To measure the "weight" of each trade, three ABC analyses (pareto diagram) has been carried out, including a criterion on the number of actual hours spent, coupled with the provisional budget and the progress of Lens 184, to check that there are no inconsistencies (Table 3). Indeed, a task with a large allocated budget that in reality requires a relatively small number of hours or that does not have a progress report in the same orders of magnitude would reflect poor management or forecasting or, more probably, an inconsistency in the data.

The construction of an $\mathrm{ABC}$ ranking has been done in the following way: the elements were classified in descending order according to the criterion considered (here the different trades classified according to the number of forecasted hours, the number of actual hours spent and the progress). Then the values were cumulated in descending order and expressed as a percentage of the total of the criterion considered. To classify, we considered the first three trades of class A, the next three of class B and the others of class C.

Table 3: ABC classification of tasks

\begin{tabular}{lccc}
\hline Tasks & Type & $\begin{array}{c}\text { Total hours spent } \\
\text { (\%) }\end{array}$ & $\begin{array}{c}\text { Expense } \\
\text { class }\end{array}$ \\
\hline Plasterwork & Plasterwork & 31 & $\mathrm{~A}$ \\
\hline Plumbing & Plumbing & 50 & $\mathrm{~A}$ \\
\hline Interior joinery & Interior carpentry & 64 & $\mathrm{~A}$ \\
\hline $\begin{array}{l}\text { Windows } \\
\text { installation }\end{array}$ & Exterior carpentry & 74 & $\mathrm{~B}$ \\
\hline Listels & Structural work & 82 & $\mathrm{~B}$ \\
\hline Sanitations & Structural work & 88 & $\mathrm{~B}$ \\
\hline Supervision & Structural work & 93 & $\mathrm{C}$ \\
\hline Finitions & Finitions & 96 & $\mathrm{C}$ \\
\hline Floors & Structural work & 99 & $\mathrm{C}$ \\
\hline Masonry & Structural work & 100 & $\mathrm{C}$ \\
\hline Restructuring & Structural work & 100 & $\mathrm{C}$ \\
\hline Locksmithing & Locksmithing & 100 & $\mathrm{C}$ \\
\hline
\end{tabular}

On one hand, this $\mathrm{ABC}$ ranking suggests that there are no inconsistencies between the progress, the estimated budget and the hours spent, because even if the order is not necessarily strictly respected for each criterion, there are no differences in categories. In other words, a trade that has a significant weight in terms of hours spent is also important in terms of the expected budget and progress. On the other hand, this classification gives a first insight into the tasks that may take a great part in construction logistics costs. 


\section{CONCLUSION}

The objective of this research paper is to quantify the economic impact of using a distribution center for a housing renovation project. While the use of distribution centers is common in industry, its introduction in construction is relatively new and the application bases are not yet in place as well as the economic model associated with this practice. Also, the economics of construction supply chains are not well documented in literature. The case study of this paper is a renovation housing project where the distribution center was used only by the general contractor and not the subcontractors. The logistics approach and the budget formulation were presented. The budget was developed thanks to the experience gained on a similar project and in the same district. The results reveal the cost and the gains associated with the use of a distribution center. The benefits depends largely on the trades associated. This paper also suggests a practical framework that assess the economics of using a distribution center in for housing. Future studies should investigate other variables that may impact the cost equation such as subcontracting practices and the type of construction (new instead of renovation).

\section{REFERENCES}

Arbulu R, Ballard G (2004) Lean Supply Systems in Construction. In: IGLC (ed) 12th Annual Conference of the International Group for Lean Construction. Helsingør, Denmark, p 13

Bock T (2015) The future of construction automation: Technological disruption and the upcoming ubiquity of robotics. Autom Constr 59:113-121. doi: 10.1016/j.autcon.2015.07.022

Caldas CH, Menches CL, Reyes PM, et al (2014) Materials Management Practices in the Construction Industry. Pract Period Struct Des Constr 20:

Court P, Pasquire C, Gibb A, Bower D (2006) Design of a Lean and Agile Construction System for a Large and Complex Mechanical and Electrical Project. In: IGLC (ed) 14th Annual Conference of the International Group for Lean Construction. Santiago, Chile

Dotoli M, Epicoco N, Falagario M, et al (2015) An integrated approach for warehouse analysis and optimization: A case study. Comput Ind 70:56-69. doi: 10.1016/j.compind.2014.12.004

Eadie R, Browne M, Odeyinka H, et al (2013) BIM implementation throughout the UK construction project lifecycle: An analysis. Autom Constr 36:145-151. doi: 10.1016/j.autcon.2013.09.001

EC Harris (2013) Supply Chain Analysis into the Construction Industry. A Report for the Construction Industrial Strategy. UK

Ekeskär A (2016) Exploring Third-Party Logistics and Partnering in Construction. Linkoping University

Ghanem M, Hamzeh F, Seppänen O, Zankoul E (2018) A New Perspective of Construction 
Logistics and Production Control: An Exploratory Study. pp 992-1001

Howell G, Ballard G (1998) Implementing Lean Construction. In: IGLC (ed) 6th Annual Conference of the International Group for Lean Construction. Guarujá, Brazil, pp 1315

Jasti NVK, Kodali R (2014) Lean production: literature review and trends. Int J Prod Res 53:867-885. doi: 10.1080/00207543.2014.937508

Lin Y-C, Cheung W-F, Siao F-C (2014) Developing mobile 2D barcode/RFID-based maintenance management system. Autom Constr 37:110-121. doi: 10.1016/j.autcon.2013.10.004

Motaghedi-Larijani A, Jabalameli M-S, Tavakkoli-Moghaddam R (2012) A network design model considering inventory cost from a third party logistics perspective. Int J Manag Sci Eng Manag 7:29-35. doi: 10.1080/17509653.2012.10671204

Ng ST, Fang Y, Ugwu OO (2008) Modelling construction material logistics system with stochastic Petri nets. Constr Innov 8:46-60. doi: 10.1108/14714170810846512

Sundquist V, Gadde LE, Hulthén K (2017) Reorganizing construction logistics for improved performance. Constr Manag Econ 6193:1-17. doi: 10.1080/01446193.2017.1356931

Vaha P, Heikkila T, Kilpelainen P, et al (2004) Construction logistics. UK

Vidalakis C, Tookey JE, Sommerville J (2011) Logistics simulation modelling across construction supply chains. Constr Innov 11:212-228. doi: $10.1108 / 14714171111124176$

Warszawski A (2003) Industrialized and Automated Building Systems: A Managerial Approach, E\&FN Spon. Taylor \& Francis Group 
Dakhli, Z., Lagier, S., Ducoulombier, L., and Lafhaj, Z. 